\title{
The Church of England and the Legislative Reforms of 1828-1832: Revolution or Adjustment?
}

\section{Nicholas Dixon ${ }^{1}$}

Since the 1950s, historians of the eighteenth- and nineteenth-century Church of England have generally maintained that the Sacramental Test Act (1828), the Roman Catholic Relief Act (1829) and the Reform Act (1832) amounted to a 'constitutional revolution', in which Anglican political hegemony was decisively displaced. This theory remains the dominant framework for understanding the effect of legislation on the relationship between church and state in pre-Victorian England. This article probes the validity of the theory. It is argued that the legislative reforms of 1828-32 did not drastically alter the religious composition of Parliament, which was already multi- denominational, and that they incorporated clauses which preserved the political dominance of the Church of England. Additionally, it is suggested that Anglican apprehensions concerning the reforming measures of 1828-32 resulted from an unfounded belief that these reforms would ultimately result in changes to the Church of England's formularies or disestablishment, rather than from the actual laws enacted. Accordingly, the post-1832 British parliamentary system did not in the short term militate against Anglican interests. In light of this reappraisal, the legislative reforms of 1828-32 may be better understood as an exercise in 'constitutional adjustment' as opposed to a 'constitutional revolution'.

Following the Reform Act and the ensuing general election of 1832, the Duke of Wellington wrote to the Conservative author John Wilson Croker:

\footnotetext{
${ }^{1}$ The research upon which this article is based was funded by an Arts and Humanities Research Council Doctoral Training Partnership studentship, grant no. 1653413, supported by Pembroke College, Cambridge. I am most grateful to Andrew Thompson for his comments and suggestions.
} 
The revolution is made, that is to say, that power is transferred from one class of society, the gentlemen of England, professing the faith of the Church of England, to another class of society, the shopkeepers, being dissenters from the Church, many of them Socinians, others atheists. $^{2}$

From 1833 onwards, this stark judgement was reinforced from within the Church of England by the emerging Oxford Movement, whose followers saw the series of reforming laws enacted by the British Parliament between 1828 and 1832 as marking a watershed in the relationship between the Church and the British state, to the detriment of the former. The Tractarian leader Richard Hurrell Froude wrote in 1833 that the 'joint effect' of the repeal of the Test and Corporation Acts, Catholic emancipation and the Reform Act had been 'to efface in at least one branch of our Civil Legislature, that character which ... qualified it to be at the same time our Ecclesiastical Legislature, and thus to cancel the conditions on which it has been allowed to interfere in matters spiritual.' This, in Froude's view, was 'a downright Revolution'. ${ }^{3}$ Such a framework of understanding became a commonplace of Tractarian and Anglo-Catholic thought. ${ }^{4}$ However, the notion of a 'revolution' taking place in 182832 was absent from most histories of the period until well into the twentieth century. As James Kirby has argued, nineteenth-century 'constitutionalist historians, Anglican and otherwise', including William Stubbs, J. R. Green and Edward Freeman, treated 'the Revolution of 1688 as the effective

${ }^{2}$ Louis J. Jennings, ed., The Correspondence and Diaries of the Late Right Honourable John Wilson Croker, LL.D., F.R.S., Secretary to the Admiralty from 1809 to 1830, 3 vols (London, 1884), 2: 2056, Duke of Wellington to John Wilson Croker, 6 March 1833.

${ }^{3}$ Richard Hurrell Froude, Remains of the Late Reverend Richard Hurrell Froude: Part the Second, 2 vols (Derby, 1839), 1: 185, 192. On Froude's theory and Anglican opposition to it, see Peter Nockles, The Oxford Movement in Context: Anglican High Churchmanship, 1760-1857 (Cambridge, 1994), 80-7.

${ }^{4}$ See e.g. George Edward Biber, Bishop Blomfield and his Times: An Historical Sketch (London, 1857), 219-23; George Anthony Denison, Notes of my Life, 1805-1878, 2nd edn (Oxford, 1878), 5960; R. W. Church, The Oxford Movement: Twelve Years 1833-1845 (London, 1891), 1-2, 41, 43; S. L. Ollard, The Anglo-Catholic Revival: Some Persons and Principles (London, 1925), 19. On the place of 1828-32 in William Ewart Gladstone's early thought, see Perry Butler, Gladstone: Church, State and Tractarianism: A Study of his Religious Ideas and Attitudes (Oxford, 1982), 79-82. 
terminus of English history. ${ }^{5}$ Correspondingly, in 1848 Thomas Babington Macaulay, contemplating the revolutions then occurring around Europe, declared 1688 to be 'our last revolution'. ${ }^{6}$ Later Whiggish historians like George Macaulay Trevelyan saw the reforming measures of 1828-32 not as having brought about a 'revolution' of any kind, but rather as having helped to avert such an outcome. ${ }^{7}$

The first historical articulation of the idea of an anti-Anglican 'revolution' occurring in 1828-32 was given by Geoffrey Best in an article of 1959. Best argued that 'despite the conspiracy of all Whigs and ... some Conservatives, to convince the public that nothing so startling as a revolution had happened', the changes of 1828-32 represented a 'constitutional revolution' of the kind posited by Wellington and the Tractarians. The repeal of the Test and Corporation Acts 'abandoned an essential principle, that of the establishment's legal and political superiority over the nonconformists.' Then, '1829 marked another betrayal of old principle', in this case with regard to Roman Catholics. Finally, 'the great change [was] sealed and confirmed by the Reform Act', which left 'the establishment ... still afloat and to outward appearances remarkably the same, but bereft of its anchors and rudder, waiting in the sultry calm to see what wind would blow and whether it could safely make any harbour.'8

Best's 'constitutional revolution' thesis became the dominant interpretation of the changing relationship between church and state in early nineteenth-century England, and is comprehensively

\footnotetext{
${ }^{5}$ James Kirby, Historians and the Church of England: Religion and Historical Scholarship, 18701920 (Oxford, 2016), 129.

${ }^{6}$ Thomas Babington Macaulay, Works, ed. Lady Trevelyan, 8 vols (London, 1866), 2: 397.

${ }^{7}$ G. M. Trevelyan, British History in the Nineteenth Century (1782-1901) (London, 1922), 220, 225. See Gordon Pentland, 'Parliamentary Reform', in David Brown, Gordon Pentland and Robert Crowcroft, eds., The Oxford Handbook of Modern British Political History (Oxford, 2018), 383-99, at 385-6.

${ }^{8}$ G. F. A. Best, 'The Constitutional Revolution, 1828-32, and its Consequences for the Established Church', Theology 62 (1959), 226-34, at 226, 228, 230-31. See also idem., Temporal Pillars: Queen Anne's Bounty, the Ecclesiastical Commissioners, and the Church of England (Cambridge, 1964), 7 , 270-71. As Best acknowledged, his arguments were to a certain extent anticipated in 1958 by Olive Brose, but she did not describe the reforms of 1828-32 as a 'revolution': Olive J. Brose, Church and Parliament: The Reshaping of the Church of England, 1828-1860 (Stanford, CA, 1959), 7-21.
} 
re-examined in this article. The thesis was further expounded by Norman Gash, Scott Bennett, G. I. T. Machin and R. K. Webb. ${ }^{9}$ In his history of England in the long eighteenth century, J. C. D. Clark put forward a variation on the theme. In Clark's schema, before 1828 England was a confessional ancien régime defined by an exclusive Anglicanism, but pressure from Catholics and dissenters presented the political elite with a clear-cut choice: 'What mattered most: monarchy or Church? In 1688-9 the political classes ultimately chose the second; in 1828-9 they reversed that choice. ${ }^{\prime} 10$ Consequently, the legislative reforms of 1828-32 were (employing another phrase of Wellington's) 'a revolution gradually accomplished', whereby any notion of an Anglican state belonged to a 'lost world' by $1838 .{ }^{11}$ Clark differed from previous historians in his shift of emphasis from 1832 to 1829 as the climax of the 'revolution'. Nonetheless, along with a growing body of historians, he upheld the essentials of Best's 'constitutional revolution' thesis.

However, beginning with that of Edward Norman in 1976, a number of relevant studies have used the term 'constitutional adjustments' to refer to the changes of 1828-32. Yet, if this signifies a rejection of the 'constitutional revolution' thesis, it is far from being explicitly so, for the thesis is not critiqued in these works. ${ }^{12}$ Jonathan Parry and Stephen Taylor have gone a little further in this

\footnotetext{
${ }^{9}$ Norman Gash, Reaction and Reconstruction in English Politics 1832-1852: The Ford Lectures delivered in the University of Oxford in the Hilary Term 1964 (Oxford, 1965), 61-2; Scott Bennett, 'Catholic Emancipation, the "Quarterly Review," and Britain's Constitutional Revolution', Victorian Studies 12 (1969), 283-304, at 285; G. I. T. Machin, Politics and the Churches in Great Britain 1832 to 1868 (Oxford, 1977), 21-2, 26-7; R. K. Webb, Modern England: From the Eighteenth Century to the Present, 2nd edn (London, 1980), 186-203.

${ }^{10}$ J. C. D. Clark, English Society 1660-1832: Religion, Ideology and Politics during the Ancien Regime, 2nd edn (Cambridge, 2000), 555.

${ }^{11}$ Ibid., 527, 563. Cf. W. H. Conser, Church and Confession: Conservative Theologians in Germany, England, and America, 1815-1866 (Macon, GA, 1984), 99-111; Richard Brown, Church and State in Modern Britain 1700-1850 (London, 1991), 203-29; Nockles, Oxford Movement in Context, 44; David Hempton, Religion and Political Culture in Britain and Ireland: From the Glorious Revolution to the Decline of Empire (Cambridge, 1996), 1, 22.

${ }^{12}$ E. R. Norman, Church and Society in England 1770-1970: A Historical Study (Oxford, 1976), 71, 77; Robert Hole, Pulpits, Politics and Public Order in England 1760-1832 (Cambridge, 1989), 229, 269; Arthur Burns, "'Standing in the Old Ways': Historical Legitimation of Church Reform in the Church of England, c. 1825-65', in R. N. Swanson, ed., The Church Retrospective (Studies in Church History 33; Woodbridge, 1997), 407-23, at 407; Arthur Burns, 'The Authority of the Church', in Peter Mandler, ed., Liberty and Authority in Victorian Britain (Oxford, 2006), 179-202,
} 
direction, stating that the legislative measures of 1828-32 were 'not in themselves revolutionary', though they do not explicate the basis of this claim. ${ }^{13}$ Perhaps the only historian explicitly to challenge the thesis has been William Gibson. In 2001, Gibson wrote of Clark's iteration of the 'constitutional revolution' thesis that 'ironically for a historian arguing frequently for the continuity of English history, it overstates the effect of the repeal of the Test and Corporation Acts and of Catholic emancipation.' In Gibson's view, the impact of 1828-29 was 'that of a change in the relationship [between Church and State] rather than a cessation of it', as ' $[\mathrm{t}]$ he monarchy, the coronation oath, the exclusion of Catholics from the succession, Church patronage, and the use of Anglicanism as an instrument of the State ensured that the Church of England remained the State religion after $1829 .{ }^{\prime} 14$

Despite Gibson's arguments, the 'constitutional revolution' thesis has remained resilient. Also in 2001, Stewart J. Brown wrote of the legislation of 1828-32, 'These changes had come so suddenly that the description of a "constitutional revolution" is an appropriate one.' Accordingly, 'the balance of power in the parliamentary State seemed to be shifting away from supporters of the established Churches to religious Dissenters'. ${ }^{15}$ The enduring dominance of the 'constitutional revolution' thesis is demonstrated by its repeated reiteration in the third volume of the Oxford History of Anglicanism, published in 2017. According to editor Rowan Strong, 'The constitutional revolution enacted by Parliament in 1828-9 meant Anglicans ceased to be the only enfranchised population in England, Wales, and Ireland, and Parliament was no longer legally solely an Anglican body, though it could

at 186; M. J. D. Roberts, Making English Morals: Voluntary Association and Moral Reform in England, 1787-1886 (Cambridge, 2008), 144.

${ }^{13}$ J. P. Parry and Stephen Taylor, 'Introduction: Parliament and the Church of England from the Reformation to the Twentieth Century', in idem., eds., Parliament and the Church, 1529-1960 (Edinburgh, 2000), 7.

${ }^{14}$ William Gibson, The Church of England 1688-1832: Unity and Accord (London, 2001), 18. See also Penelope Corfield's critique of Clark's related notion of England as a 'confessional state': Penelope Corfield, 'Georgian England: One State, Many Faiths', History Today 45 (1995), 14-21. 15 Stewart J. Brown, The National Churches of England, Ireland, and Scotland 1801-46 (Oxford, 2001), 168. Cf. Richard W. Davis, A Political History of the House of Lords, 1811-1846 (Stanford, CA, 2008), 141. 
still legislate for the Church of England." ${ }^{16}$ Brown writes that "the "constitutional revolution" of 1828-32 ... had largely ended the confessional state in the United Kingdom and weakened the influence and authority of the Established Church of England.' ${ }^{17}$ Robert Andrews also endorses the theory, arguing that from 1832, 'Parliament, which for centuries had been a sort of Anglican "lay synod", was now officially a mixed body in terms of religious confessions.' ${ }^{18}$

In its various permutations, the 'constitutional revolution' thesis relies on three basic assumptions: firstly, that prior to 1828 the British Parliament was in essence an exclusively Anglican body; secondly, that the legislation of 1828-32 removed the legal underpinnings of the Church of England's political dominance; and, thirdly, that the effect of these laws was to diminish the Church's political role. Yet all three of these assumptions are questionable. The purpose of this article is twofold: to re-evaluate the assumptions upon which the 'constitutional revolution' thesis is grounded, and to discuss how contemporary perceptions that a 'revolution' had occurred, such as Wellington's, should be contextualised. Additionally, the article will consider whether the measures of 1828-32 may be better understood as an exercise in 'constitutional adjustment'. While it primarily concerns the legislative evidence bearing upon the 'constitutional revolution' thesis, this article also involves a wider consideration of the political and religious ramifications of the laws of 1828-32.

The first assumption - that prior to 1828 Parliament was essentially an exclusively Anglican body - derives from Froude's interpretation of Richard Hooker's Laws of Ecclesiastical Polity. Arguing from Hooker that the realm and church were coterminous, Froude asserted that from the Reformation the English (and later British) Parliament had been akin to a 'lay synod', whereby the Church of

\footnotetext{
${ }^{16}$ Rowan Strong, 'Introduction', in idem., ed., The Oxford History of Anglicanism, 3: Partisan Anglicanism and its Global Expansion 1829-c.1914 (Oxford, 2017), 1-23, at 1. See also idem., 'Anglicanism and the State in the Nineteenth Century', in ibid., 92-115, at 93-4, 105, 111.

${ }^{17}$ Stewart J. Brown, 'Anglicanism in the British Empire, 1829-1910', in ibid., 45-68, at 46.

${ }^{18}$ Robert M. Andrews, 'High Church Anglicanism in the Nineteenth Century', in Strong, Partisan Anglicanism, 141-64, at 145-6, and see also 153, 158, 162. Cf. Stewart J. Brown, Providence and Empire: Religion, Politics and Society in the United Kingdom 1815-1914 (Harlow, 2008), 178; Frances Knight, The Church in the Nineteenth Century (London, 2008), 14-15.
} 
England had been governed by its members. ${ }^{19}$ However, the notion of a parliamentary 'lay synod' was absent from constitutional thought before the 1830s. The only deliberative bodies resembling Anglican synods in England were the convocations of Canterbury and York, which were exclusively clerical and seldom transacted anything beyond the composition of loyal addresses to the monarch between 1718 and $1852 .^{20}$

Indeed, the assertion that the post-Restoration English Parliament was, in any meaningful sense, an Anglican 'lay synod' would have represented a blatant denial of reality. ${ }^{21}$ From 1660 to 1678 , Catholics sat in Parliament, and dissenters (with the exception of Quakers) were never legally barred from being Members of Parliament. ${ }^{22}$ The restrictions that did emerge were of an uneven and ambiguous character. By the Corporation Act of 1661, members of English and Welsh corporations had to receive Anglican communion, but this requirement was not extended to legislators. ${ }^{23}$ The Test Act of 1673 stipulated that all holders of civil and military offices in England and Wales had to take oaths of supremacy and allegiance, declare that they did not believe in transubstantiation and receive Anglican communion. ${ }^{24}$ By the Test Act of 1678, all peers and members of the House of Commons had to declare that they did not believe in transubstantiation and certain other Catholic doctrines. ${ }^{25}$ The 'Glorious Revolution' of 1688 led to the Toleration Act of 1689, allowing freedom of worship to dissenters in England and Wales on certain conditions, but did not alter the test legislation passed

\footnotetext{
${ }^{19}$ Froude, Remains, 1: 196-207.

${ }^{20}$ Gerald Bray, ed., Records of Convocation, 20 vols (Woodbridge, 2006), vols 11-12, 15.

${ }^{21}$ Froude was aware of his theory's shortcomings and, according to Peter Nockles, his 'appeal to Hooker had been an essentially rhetorical, tactical device to disarm the "Zs" ['old' high churchmen]': Nockles, Oxford Movement in Context, 80. He even admitted to Newman that the 'facts' employed in support of his case were 'less satisfactory than I could wish - I find that the Test and Corporation Acts applied only indirectly to Members of Parliament': I. Ker and T. Gornall, eds., The Letters and Diaries of John Henry Newman, 4: The Oxford Movement, July 1833 to December 1834 (Oxford, 1980), 38, Richard Hurrell Froude to John Henry Newman, [August 1833].

22 Basil Duke Henning, ed., The History of Parliament: The House of Commons 1660-1690, 3 vols (London, 1983), 1: 12. Quakers were effectively excluded from Parliament because of the requirement for MPs to take an oath of office, which was repealed in 1833: 3 \& 4 Will. 4, c. 49.

2313 Cha. 2, c. 1.

2425 Cha. 2, c. 2.

2530 Cha. 2, c. 1.
} 
during the reign of Charles II. ${ }^{26}$ Occasional conformity, whereby dissenters communicated in Anglican churches to qualify for civil office but continued to frequent their own places of worship, became widespread, but was banned by an act of the British Parliament in $1711 .{ }^{27}$ However, this act was repealed in 1719 and, sporadically from 1726 and annually from 1757, indemnity acts were passed, effectively abrogating the requirements of the 1661 and 1673 test acts as far as English and Welsh dissenters were concerned. ${ }^{28}$

Though Anglicans predominated in Parliament throughout the long eighteenth century, the Corporation Act and the Test Acts did not ever make Parliament an exclusively Anglican 'lay synod'. This was especially so after the Acts of Union between England and Scotland (1706-7), whereby Scottish MPs and representative peers joined their English and Welsh counterparts in Westminster to legislate for a bi-confessional United Kingdom; Scottish MPs and representative peers were subject to the Test Act of 1678 but were exempted from the Test Act of 1673, which contravened the Presbyterian standard of the Church of Scotland that had supplanted Episcopalianism in Scotland in 1689-90. ${ }^{29}$ However, Scottish Presbyterians were not the only nonAnglicans sitting in Parliament. At least thirty-nine English and Welsh dissenters sat in the House of Commons between 1690 and 1715; at least twenty-eight between 1715 and 1754; and at least

261 Will. \& Mary, c. 18; James E. Bradley, Religion, Revolution, and English Radicalism: Nonconformity in Eighteenth-century Politics and Society (Cambridge, 1990), 51-2.

2710 Anne, c. 6; Bradley, Religion, Revolution, and English Radicalism, 52-3.

285 Geo. 1, c. 4; K. R. M. Short, 'The English Indemnity Acts 1726-1867', Church History 42 (1973), 366-76; Bradley, Religion, Revolution and English Radicalism, 69-84. Also crucial to the equation was the 'Act for Quieting and Establishing Corporations' (1719), which gave members of corporations who held office for six months immunity from prosecution under the Corporation Act: 5 Geo. 1, c. 6. Additionally, from 1722 to 1851, dissenting churches received Treasury funding: K. R. M. Short, 'The English Regum Donum', English Historical Review 84 (1969), 59-78.

${ }^{29} 6$ Anne, c. $11 ; 1707$, c. 7. 
nineteen between 1754 and $1790 .{ }^{30}$ In total, from 1790 to 1820 , just under sixty MPs were not members of the established churches of England, Scotland or Ireland. ${ }^{31}$

Of course, there remained a ban on Catholic parliamentarians, perpetuated by the Acts of Union with Ireland (1800) whereby Irish peers and MPs were made subject to the Test Act of $1678 .{ }^{32}$ However, even this restriction had come under significant pressure in the later eighteenth century. Between 1754 and 1790, at least eight MPs were former Catholics who had renounced their faith to sit in Parliament. ${ }^{33}$ The converts with the highest profile were Sir Thomas Gascoigne and Charles Howard, Earl of Surrey, who in 1780 were received into the Church of England by the Archbishop of Canterbury at Lambeth Palace. ${ }^{34}$ Despite having renounced their former confession, both promoted Catholic interests in Parliament, and, in the view of many contemporaries, were not sincere converts. According to Nathaniel Wraxall, the Earl of Surrey was known to assert when intoxicated 'that three as good Catholics sate in Lord North's last Parliament as ever existed, namely, Lord Nugent, Sir Thomas Gascoyne, and himself'. ${ }^{35}$ As Alexander Lock writes, 'there was seemingly some truth in Surrey's statement'. ${ }^{36}$ Tellingly, Lord Nugent, an Irish Catholic who had become Anglican to represent St Mawes and Bristol, reverted to his Catholicism after he left the House of Commons with an Irish peerage. ${ }^{37}$ In any case, eighteenth-century parliamentarians were not above concealing their religious allegiance for the sake of political expedience. Frederick North, Earl of Guilford, sat as

\footnotetext{
${ }^{30}$ D. W. Hayton, ed., The History of Parliament: The House of Commons 1690-1715, 5 vols (Cambridge, 2002), 1: 311; Romney Sedgwick, ed., The History of Parliament: The House of Commons 1715-1754, 2 vols (London, 1970), 1: 139; L. B. Namier and J. Brooke, eds., The History of Parliament: The House of Commons 1754-1790, 3 vols (London, 1964, repr. 1985), 1: 115.

${ }^{31}$ R. G. Thorne, ed., The History of Parliament: The House of Commons 1790-1820, 5 vols (London, 1986), 1: 294.

$3239 \& 40$ Geo. 3, c. $67 ; 40$ Geo. 3, c. 38. By an act of the Irish Parliament that was passed in 1780, dissenters, though not Catholics, could hold civil office in Ireland: 20 Geo. 3, c. 6.

${ }^{33}$ Alexander Lock, Catholicism, Identity and Politics in the Age of Enlightenment: The Life and Career of Sir Thomas Gascoigne, 1745-1810 (Woodbridge, 2016), 97.

${ }^{34}$ Ibid., 98-101.

${ }^{35}$ Nathaniel Wraxall, Posthumous Memoirs of his own Time, 3 vols (London, 1836), 1: 32.

${ }^{36}$ Lock, Thomas Gascoigne, 109.

${ }^{37}$ Ibid., 109; Namier and Brooke, House of Commons 1754-1790, 3: 219, 222.
} 
both an MP for Banbury and a peer after his secret conversion to the Greek Orthodox Church whilst visiting Corfu in 1791. After a parliamentary career of 35 years, an Orthodox priest was summoned to his deathbed in $1827 .^{38}$

Having established that Parliament was far from exclusively Anglican prior to 1828 , it is possible to evaluate the true nature of the reforming legislation enacted from 1828 to 1832 . By the Sacramental Test Act of 1828, the Corporation Act of 1661 and the Test Act of 1673 were repealed, removing the requirement for members of corporations and officeholders in England and Wales to take Anglican communion. ${ }^{39}$ Some of the strongest opposition to the sacramental test had come from the Anglican clergy, who viewed it as a profanation of the sacrament. ${ }^{40}$ Hence when Home Secretary Robert Peel proposed replacing sacramental tests with a positive declaration that an officeholder would not harm Anglican interests, the bishops were receptive. Peel's closest confidante on the episcopal bench was his former college tutor, Charles Lloyd, Bishop of Oxford, who was of the opinion that 'the best thing for the Church of England would be that it should pass, if that could be managed without a positive surrender of principle on the part of the Bishops. ${ }^{41}$ William Van Mildert, Bishop of Durham, told Lloyd that he was not 'anxious to retain the Sacramental Test, if any other, equally efficacious, seemly \& respectful, as indicating an acknowledgement of the ascendancy of the Church, can be devised. ${ }^{42}$ Peel ascertained the views of seven prelates, before meeting with six at Lambeth Palace, where, as he reported to Lloyd, '[w]e settled a declaration' ${ }^{43}$

In its final form, the new declaration required officeholders in England and Wales to assert that they would 'never exercise any Power, Authority, or Influence ... to injure or weaken the Protestant

\footnotetext{
${ }^{38}$ Kallistos Ware, 'The Fifth Earl of Guilford and his Secret Conversion to the Orthodox Church', in Peter M. Doll, ed., Anglicanism and Orthodoxy 300 Years after the 'Greek College' in Oxford (Oxford, 2006), 290-326.

399 Geo. 4, c. 17.

${ }^{40}$ London, BL, Add MS 40343, fo. 189v , Charles Lloyd to Robert Peel, 2 March 1828; ibid., fol. $247^{\mathrm{v}}$, Lloyd to Peel, 23 March 1828.

${ }^{41}$ Ibid., fol. 190v , Lloyd to Peel, 2 March 1828.

${ }^{42}$ Ibid., fol. 203 ${ }^{\text {, }}$ William Van Mildert to Lloyd, 3 March 1828.

${ }^{43}$ Ibid., fol. 205, Peel to Lloyd, 4 March 1828; ibid., fol. 212 ${ }^{\text {r }}$, Peel to Lloyd, 15 March 1828.
} 
Church as it is by Law established in England, or to disturb the said Church, or the Bishops and Clergy of the said Church, in the Possession of any Rights or Privileges to which such Church, or the said Bishops and Clergy, are or may be by Law entitled. ${ }^{44}$ Peel considered this a more effective safeguard for Anglican interests than the defunct sacramental test: 'The difference between a declaration and a Test like the present is certainly enormous, if you will bona fide act upon your Test, but 85 years' relaxation of it, and the notorious inability to enforce the Test without absolute confusion, change the nature of the difference, and in my opinion, all in favour of the declaration.' 45 The resulting act was, according to Bishop Blomfield of London, 'strictly and literally a measure of the Bishops. ${ }^{46}$ The Sacramental Test Act had no practical effect on dissenting participation either in Parliament or in corporations (although the latter was already protected by indemnity acts).

Furthermore, it did not remove the need for indemnity acts, which continued to be passed by Parliament annually until 1867 , though these now suspended the requirement to make the new declaration as opposed to the previous sacramental test. ${ }^{47}$ The only significant opposition to the repeal of the Corporation and Test Acts came from Lord Eldon, who believed that 'the Church of England, combined with the state, formed together the constitution of Great Britain, and that the Test and Corporation acts were necessary to the preservation of that Constitution.' ${ }^{48}$ Contrary to Richard Davis's assertion, Eldon's view was not one with which '[m] ost ... would have agreed'. ${ }^{49}$ As G. I. T.

449 Geo. 4 , c. 17.

${ }^{45}$ BL, Add MS 40343, fo. 252, Peel to Lloyd, 25 March 1828.

${ }^{46}$ A. Blomfield, ed., A Memoir of Charles James Blomfield, D.D., Bishop of London, with Selections from his Correspondence, 2 vols (London, 1863), 1: 138, Charles Blomfield to James Henry Monk, 22 April 1828. On the bishops' role in securing the act and declaration, see R. A. Gaunt, 'Peel's Other Repeal: The Test and Corporation Acts, 1828', Parliamentary History, 33 (2014), 243-62, at 253-7.

${ }^{47}$ Short, 'English Indemnity Acts', 376.

${ }^{48}$ Hansard, 2nd Series, 18: 1576 (21 April 1828).

${ }^{49}$ Davis, House of Lords, 141. 
Machin showed in 1979, extra-parliamentary opposition to the repeal of the Corporation and Test Acts was confined to a few petitions, newspaper items and pamphlets, and never gained traction. ${ }^{50}$

The 1828 act was therefore far from revolutionary; if anything, it gave a clearer recognition of the Church's constitutional dominance than had existed since the introduction of regular indemnity acts. The Roman Catholic Relief Act of 1829, carried by Wellington and Peel, may be viewed in a similar light. Popular and episcopal opposition and the turbulent political situation in Ireland following the County Clare by-election made the measure much more controversial than the Sacramental Test Act, but the underlying principle of the two Acts was very similar. ${ }^{51}$ The Roman Catholic Relief Act repealed the Test Act of 1678, and stipulated that Catholics entering Parliament should take oaths of allegiance and declare that they did 'not believe that the Pope of Rome, or any other Foreign Prince, Prelate, Person, State or Potentate, hath or ought to have any Temporal or Civil Jurisdiction, Power, Superiority or Pre-eminence, directly or indirectly, within this Realm.' They were also to 'disclaim, disavow, and solemnly abjure any Intention to subvert the present Church Establishment as settled by Law within this Realm'. Additionally, the act forbade Catholics from holding such high offices as Lord Chancellor and specified provisions for the 'gradual Suppression and final Prohibition' of the Jesuit order in the United Kingdom. ${ }^{52}$ Simultaneously, Irish forty-shilling freeholders, who constituted the majority of the Catholic electorate, were disenfranchised, a provision which led to significant unrest in Ireland. ${ }^{53}$

${ }^{50}$ G. I. T. Machin, 'Resistance to Repeal of the Test and Corporation Acts', The Historical Journal 22 (1979), 115-39, at 126-32.

${ }^{51}$ On the events which led to the passage of Catholic emancipation, see G. I. T. Machin, The Catholic Question in English Politics, 1820 to 1830 (Oxford, 1964); Wendy Hinde, Catholic Emancipation: A Shake to Men's Minds (Oxford, 1992).

5210 Geo. 4 , c. 7.

${ }^{53} 10$ Geo. 4, c. 8. On this disenfranchisement, see David A. Bateman, Disenfranchising Democracy: Constructing the Electorate in the United States, the United Kingdom, and France (Cambridge, 2018), 246-9. 
While to Whigs like Henry Bathurst, Bishop of Norwich, the Roman Catholic Relief Act represented a 'triumph of civil and religious liberty', the papacy did not view it in the same light. ${ }^{54}$ In a discussion with Peter Baines, the Catholic Vicar Apostolic of the Western District of England, concerning the declaration imposed by the act, Pope Pius VIII indicated that he could not 'approve a formula so loosely and incautiously worded, containing, moreover, insinuations grossly injurious to the Catholic religion, and to the Holy See in particular', though neither would he condemn it. ${ }^{55}$ Yet, with the approval of the Vicars Apostolic, a small number of Catholics took the oath. ${ }^{56}$

The final element in the supposed 'constitutional revolution' of 1828-32 did not directly concern the religious allegiance of parliamentarians. By the Reform Act of 1832, which was carried under Earl Grey’s Whig government, uniform property qualifications for voting were introduced, new county and borough seats were created and other seats, mostly the notorious 'rotten boroughs', were abolished. ${ }^{57}$ The Church of England at large did not oppose the principle of parliamentary reform, which was supported by a sizeable proportion of Tory politicians and newspapers with the express intention of ensuring that Anglican opinion could not be disregarded, as they perceived it to have been with the passage of Catholic emancipation in $1829 .{ }^{58}$ One of the earliest post-1829 schemes for wholesale parliamentary reform, that proposed by the Marquis of Blandford in February 1830, included the re-admission of Anglican clergymen to the House of Commons, from which they had been barred since $1801 .{ }^{59}$ When the second Reform Bill came before the Lords in November 1831,

\footnotetext{
${ }^{54}$ T. Thistlethwayte, Memoirs and Correspondence of Dr. H. Bathurst, Lord Bishop of Norwich (London, 1853), 352, Henry Bathurst to Thomas William Coke, 16 April 1829.

${ }^{55}$ Hansard, 3rd Series, 42: 967-8 (8 May 1838); Owen Chadwick, The Victorian Church: Part I, 3rd edn (London, 1971), 22.

${ }^{56}$ Chadwick, Victorian Church, 22-3; John A. Stack, 'Catholic Members of Parliament who represented British Constituencies, 1829-1885: A Prosopographical Analysis', Recusant History 24 (1999), 335-63, at 348.

572 \& 3 Will. 4, c. 45. On the Reform Act, see M. G. Brock, The Great Reform Act (London, 1973); Jonathan Parry, The Rise and Fall of Liberal Government in Victorian Britain (New Haven, CT, 1993), 72-89.

${ }^{58}$ James J. Sack, From Jacobite to Conservative: Reaction and Orthodoxy in Britain, c. 1760-1832 (Cambridge, 1993), 152-5; Clark, English Society, 536-7.

${ }^{59}$ Hansard, 2nd Series, 22: 692-3 (18 February 1830).
} 
the bishops were divided as to the details of the measure, but, as Lord Ellenborough observed, 'all for Reform' ${ }^{60}$ Indeed, Henry Phillpotts, Bishop of Exeter, wished that 'some specific measure were started' on their part. ${ }^{61}$ However, the bishops' twenty-one votes against the second Reform Bill helped to block its passage, allowing radicals to lambast them as the inveterate enemies of all reform. ${ }^{62}$ This criticism was belied by the willingness of twelve bishops to vote on pragmatic grounds for the third Reform Bill, which became the Reform Act of $1832 .{ }^{63}$

Was the effect of such measures fatally to undermine the political position of the Church of England? Many Anglican clergymen certainly believed so. Yet their despair at the laws of 1828-32 was not so much conditioned by the legislation itself as by an unfounded fear that disestablishment or worse was imminent. The measures of $1828-32$ were perceived as indirectly destructive of the Church of England's formularies and status as a 'national' church. As Thomas Rennell, Dean of Winchester, put it in 1829, 'What was begun in the repeal of the test \& Corporation act [sic] continued in the Popish Emancipation, will be consummated in the disfigurement \& exinanition of our Liturgy \& Articles. ${ }^{94}$ George Huntingford, Bishop of Hereford, commented, 'How is it possible for me not to dread the arrival of that period, when the Papist Legislators shall feel their strength \& degrade the Protestant Church of Ireland? ... I am convinced degradation of our own Church will soon follow the spoliation and decadence of the Irish Ecclesiastical Establishment. ${ }^{65}$ In 1832, Henry

${ }^{60}$ Diary of Lord Ellenborough, 8 October 1831, in: Arthur Aspinall, ed., Three Early Nineteenth Century Diaries (London, 1952), 144.

${ }^{61}$ Henry Phillpotts to Ralph Barnes, 8 October 1831, in: G. C. B. Davies, Henry Phillpotts, Bishop of Exeter, 1778-1869 (London, 1954), 113.. Phillpotts did not, however, specify concrete proposals. ${ }^{62}$ Ibid., 109-10, 114, 139; Chadwick, Victorian Church, 26-32; Elizabeth Varley, The Last of the Prince Bishops: William Van Mildert and the High Church Movement of the Early Nineteenth Century (Cambridge, 1992), 145-8; J. R. Garrard, Archbishop Howley, 1828-1848 (Farnham, 2015), 47-8.

${ }^{63}$ Hansard, 3rd Series, 12: 455-6 (13 April 1832). On the bishops' attitudes to the Reform Bills, see Davies, Henry Phillpotts, 102-4, 109-14, 130-40; Norman, Church and Society, 83-9; Varley, William Van Mildert, 145-7; Garrard, Archbishop Howley, 44-8.

64 Thomas Rennell to Henry Handley Norris, 15 December 1829: Oxford, Bodl., MS. Eng. lett. c. 789 , fol. $203^{\mathrm{v}}$.

${ }^{65}$ George Isaac Huntingford to Thomas Burgess, 6 May 1829: Bodl., MS. Eng. lett. c. 136, fol. 107r ${ }^{\mathrm{r}}$. 
Handley Norris, Perpetual Curate of Hackney, wrote that he saw 'an undercurrent of conspiracy ready to rise and sweep all before it, as soon as that which is now upon the surface has done its destruction'. ${ }^{66}$ As Robert Saunders has noted, some Anglican preachers responded to the Reform crisis by asserting divine authority over human affairs.$^{67}$

Other Church of England clergy went even further than this in their apprehensions concerning the results of Catholic emancipation in particular. George Lowther, curate of Longford in Derbyshire, placed a letter in a bottle beneath a new pulpit in 1826, prophesying: 'I feel strongly assured that when these papers see the light it will be under the hierarchy of the Roman Catholic Church which will doubtless gain the ascendancy in proportion as ignorance prevails: and I cannot help predicting the downfall of the English nation, as I fancy I behold in it all the signs of a declining state. ${ }^{68}$ John Skinner, Rector of Camerton in Somerset, wrote in his journal in 1828: 'Alas! how can our senators know what will be the result of their absurd concessions! Should my papers survive, it will be manifest what was the state of society in the time I wrote, and the determination of one person at least among the millions of Britain to oppose the torrent of iniquity which in all probability will bear him away with it. ${ }^{69}$ Simultaneously, the pre-millenarian Anglican Henry Drummond, soon to secede and assist in forming the Catholic Apostolic Church, saw 1828-29 as a portent of the apocalypse. ${ }^{70}$

By contrast, Bishop Bathurst wrote of the Church in 1832 that he did 'not think it in any danger at present' ${ }^{71}$ In the short term, this lack of alarm was vindicated. The dissenting electorate may have

\footnotetext{
${ }^{66}$ Norris to William Howley, 25 October 1832: London, LPL, MS 2185, fol. 95.

${ }^{67}$ Robert Saunders, 'God and the Great Reform Act: Preaching Against Reform, 1831-32', Journal of British Studies 53 (2014), 378-99, at 390-96.

${ }^{68}$ Quoted in Michael Austin, 'A Time of Unhappy Commotion': The Church of England and the People in Central Nottinghamshire 1820-1870 (Chesterfield, 2010), 12.

${ }^{69}$ John Skinner, Journal of a Somerset Rector 1803-1834, ed. H. Coombs and P. Coombs (Bath, 1971), 354.

${ }^{70}$ Boyd Hilton, A Mad, Bad, and Dangerous People? England 1783-1846 (Oxford, 2006), 405.

${ }^{71}$ Norwich, Norfolk Record Office, DCN 154/2/117, Henry Bathurst to James Bathurst, 18 June 1832. This was a modification of Bathurst's opinion, expressed the previous year, that ' $[\mathrm{w}] \mathrm{e}$ are told incessantly by the High Church party, that our Ecclesiastical Establishment is in danger, and so it certainly is; but this danger arises from a want of temper and moderation in too many of the clergy,
} 
increased as a result of the Reform Act, but the number of English dissenting MPs did not, standing at eight in $1833 .{ }^{72}$ The number of English nonconformists in the Commons increased during the succeeding decades, but its nineteenth-century peak in 1892 was only 117 in a house of $670 .{ }^{73}$ Four English Catholic MPs entered the House of Commons in 1830, but by 1837 there were only two. The number rose to six in the 1840s, but from 1852 to 1885 there were never more than three English Catholic MPs, with none sitting between 1874 and $1880 .{ }^{74}$ Only two Catholics are known to have served as cabinet ministers between 1829 and 1895, while Queen Victoria displayed a decided reluctance to create any Catholic peers. ${ }^{75}$ Among the 105 Irish seats in the Commons, Protestant members predominated until the $1880 \mathrm{~s} .{ }^{76}$ No Catholic MPs were elected in Scotland until 1885. ${ }^{77}$ Hence after 1832 the vast majority of legislators remained Protestant, with Anglicans still in preponderance.

Furthermore, Whig attempts to dismantle aspects of Anglican hegemony foundered in Parliament during the remainder of the 1830s. The Whigs managed to reduce the number of Irish dioceses, increase dissenting participation in local government through the Municipal Corporations Act (1835), legally recognise marriages in dissenting places of worship and commute tithe payments. ${ }^{78}$ Nevertheless, parliamentary opposition ensured that they failed in attempts to admit dissenters to full

and also from their selfish opposition to a Commutation of Tithes': Thistlethwayte, Memoirs, 384, Henry Bathurst to Coke, 10 September 1831.

${ }^{72}$ S. F. Woolley, 'The Personnel of the Parliament of 1833', English Historical Review 53 (1938), 240-62, at 244; Roger Anstey, 'Parliamentary Reform, Methodism and Anti-Slavery Politics, 18291833', Slavery and Abolition 2 (1981), 209-26, at 220-22.

${ }^{73}$ Simon Skinner, 'Religion' in David Craig and James Thompson, eds., Languages of Politics in Nineteenth-century Britain (Basingstoke, 2013), 93-117, at 110.

${ }^{74}$ Stack, 'Catholic Members of Parliament', 348.

${ }^{75}$ Dennis Grube, At the Margins of Victorian Britain: Politics, Immorality and Britishness in the Nineteenth Century (London, 2013), 82-3.

${ }^{76}$ Kimberly Cowell-Meyers, Religion and Politics in the Nineteenth Century: The Party Faithful in Ireland and Germany (Westport, CT, 2002), 80.

${ }^{77}$ Tom Gallagher, Glasgow, the Uneasy Peace: Religious Tension in Modern Scotland, 1819-1914 (Manchester, 1987), 23.

783 \& 4 Will. 4, c. 37; 5 \& 6 Will. 4, c.76; 6 \& 7 Will. 4, c. 71; 6 \& 7 Will. 4, c. 185; 1 \& 2 Vict., c. 109. 
membership of the universities of Oxford and Cambridge, to abolish church rates and to introduce a nondenominational system of state education. ${ }^{79}$ During Peel's brief premiership of $1834-35$, a moderate and consensual, though not uncontroversial, mode of church reform was inaugurated in the form of the Ecclesiastical Commission. ${ }^{80}$ Meanwhile, the Anglican clergy were instrumental in the organisation and growth of Peel's Conservative party at a local level, and a major factor in the party's increasingly successful electoral performance. ${ }^{81}$ In their election campaigning rhetoric, Conservative candidates presented themselves as defenders of 'Church, Constitution and King', 'your Church and Constitution', the 'Protestant Constitution' and 'our Glorious Constitution in Church and State' ${ }^{82}$ The non-Tractarian, Conservative-leaning majority of Anglicans evidently adopted the view that there was still an Anglican constitution to defend.

Though it lies beyond the scope of this article to examine events beyond the 1830s in detail, the genuine 'constitutional revolution', if such there was, came in the period from 1854 to 1871 . These years saw the abolition of the declarations imposed on Catholics and dissenters in 1828-29, the excision from the Prayer Book of three services (those which commemorated Charles I's execution, the Restoration and the Gunpowder Plot as well as William III's arrival in England), the abolition of compulsory church rates, the disestablishment of the Church of Ireland and the abolition of religious

${ }^{79}$ Hansard, 3rd Series, 25: 886 (1 August 1834); J. P. Ellens, 'Lord John Russell and the Church Rate Conflict: The Struggle for a Broad Church, 1834-1868', Journal of British Studies 26 (1987), 232-57, at 238-42; Ian D. C. Newbould, 'The Whigs, the Church, and Education, 1839', Journal of British Studies 26 (1987), 332-46. Before the 1850s, subscription to the Thirty-Nine Articles of the Church of England was required for matriculation and graduation at the University of Oxford; the University of Cambridge did not require subscription for matriculation, but like Oxford enforced it for graduation: Gibson, Unity and Accord, 137-8.

${ }^{80}$ Brose, Church and Parliament, 120-56; Best, Temporal Pillars, 296-347.

${ }^{81}$ Philip Salmon, Electoral Reform at Work: Local Politics and National Parties 1832-1841 (Woodbridge, 2002), 69-72, 99-101.

82 See e.g. Cambridge, Cambridgeshire Archives, R89/82/90, 'John Bull', 'Summons to Conservatives', 5 January 1835; Essex Standard, 16 January 1835, 2; Warwick, Warwickshire Record Office, DR362/133, Evelyn Shirley, 'To the Electors of the Southern Division of the County of Warwick', 17 June 1836; Bolton, Bolton Archives, ZZ/130/3/12, Samuel Scowcroft, 'To the Worthy Electors of the Borough of Bolton', 19 July 1837. 
tests for membership of the universities of Oxford, Cambridge and Durham. ${ }^{83}$ Viewed in the light of such transformative measures, the effect of the legislation of 1828-32 on the Church of England appears comparatively insignificant.

What really occurred between 1828 and 1832 was not a 'revolution' but an 'adjustment' of the British constitution, at least so far as the Church of England was concerned. '[S]atisfactory \& safe adjustment' was what Peel professed to advocate in 1829, and this, in a large measure, was what he, Wellington and Grey achieved. ${ }^{84}$ Before 1828 , Parliament was a multi-confessional body dominated by Anglicans, and it would remain so after 1832. The Sacramental Test Act and the Roman Catholic Relief Act, far from depriving the Church of England of significant privileges, perpetuated Anglican primacy through the declarations they prescribed. Moreover, the Reform Act did not lead, as Wellington had simplistically supposed, to government by dissenting shopkeepers, even if more dissenters were enfranchised. ${ }^{85}$ Additionally, Anglican apprehensions that reforming legislation would lead inexorably to disestablishment were quickly demonstrated to be groundless. Hence the framework of 'constitutional adjustment' latent in certain historians' writings should be employed in contradistinction to the notion of a 'constitutional revolution', rather than complementing it. In the light of this reinterpretation, much that has been taken for granted about the relationship between church and state in nineteenth-century England is called into question. For if there was no 'constitutional revolution' in 1828-32, we must consider the possibility that Anglican socio-political dominance was both more resilient and more adaptable than historians have previously imagined.

${ }^{83} 17$ \& 18 Vict., c. $81 ; 19$ \& 20 Vict., c. $88 ; 21$ \& 22 Vict., c. $48 ; 29$ \& 30 Vict., c. 22; London Gazette, 18 January 1859, 161; 31 \& 32 Vict., c. 109; $32 \& 33$ Vict., c. 42 ; 34 \& 35 Vict., c. 26. ${ }^{84}$ BL, Add MS 40343, fo. 330, Peel to Lloyd, 15 January 1829. Cf. BL, Add MS 40415, fo. 137v, Peel to Van Mildert, 23 February 1835.

${ }^{85}$ Machin writes that Wellington's statement was 'wildly exaggerated', but there is reason to think that the statement not so much an exaggeration as a misrepresentation of the Reform Act's effects: Machin, Politics and the Churches, 26. 